\title{
DITERIMANYA IZIN POLIGAMI KARENA INGIN MENDIDIK DAN MENOLONG CALON ISTRI DALAM PENETAPAN PA SIDOARJO NO. 1913/PDT.G/2015/PA.SDA
}

\begin{abstract}
Muhammad Salim
Madrasah Aliyah Negeri 2 Model Pekanbaru Jl. Diponegoro No. 55, Pekanbaru, Riau. Email: Jorzarbakau@Yahoo.Co.Id

Abstract: This article is a normative study of the determination of the Sidoarjo Religious Court in case No.1913 / Pdt.G / 2015 / PA. regarding the receipt of a polygamy permit application because the husband wants to educate and belp the second prospective wives. This study is interesting considering that this reason is not at all listed in Law No. 1 of 1974 concerning marriage. The judge has three considerations. First, the condition of the applicant's second wife is mentally traumatized because she has experienced domestic violence in a previous marriage. second, in the Koran are required only fair. Third, there has been an agreement from the first wife, fulfilled materially and non materially by the applicant and able to be fair by making a statement. Even though the judge ignored the law in this matter, however, the value of benefit would be greater if he received the polygamy permit application. The judge may give a different verdict, but if it continues to do so the limitation of polygamy regulations will be weak. What did the judges were in accordance with article 4, paragraph 2 of Law No. 1 of 1974 and Law No. 48 Year 2009 concerning Judicial Authority Article 1 Paragraph 1.
\end{abstract}

Keywords: permission for polygamy, educating and helping prospective wives

Abstrak: artikel ini adalah kajian normatif terhadap penetapan Pengadilan
Agama Sidoarjo dalam perkara No.1913/Pdt.G/2015/PA.Sda. tentang
diterimanya permohonan izin poligami karena ingin mendidik dan
menolong calon istri. Kajian ini menarik mengingat bahwa alasan tersebut
sama sekali tidak tercantum dalam Undang-Undang Nomor 1 Tahun 1974
Tentang perkawinan. Hakim memiliki tiga pertimbangan, Pertama, kondisi
calon istri kedua pemohon secara mental trauma karena pernah mengalami
KDRT pada perkawinan sebelumnya. Kedua, dalam al-Quran hanya
disyaratkan adil. Ketiga, sudah adanya persetujuan dari istri pertama,
terpenuhi secara materi maupun non materi oleh pemohon dan sanggup
adil dengan membuat surat pernyataan. Walaupun hakim mengabaikan
undang-undang dalam hal ini, akan tetapi, nilai kemaslahatan akan lebih
banyak jika menerima permohonan izin poligami tersebut. Hakim boleh
memberikan putusan yang berbeda, akan tetapi jika itu terus dilakukan
maka pembatasan peraturan poligami secara ketat akan terjadi lemah. Apa
yang dilakukan hakim sudah sesuai pasal 4 ayat 2 Undang-Undang Nomor

AL-HUKAMA

The Indonesian Journal of Islamic Family Law

Volume 07, Nomor 01, Juni 2017; ISSN:2089-7480 
Muahammad Salim: Diterimanya Izin Poligami...

1 Tahun 1974 dan Undang-Undang Nomor 48 Tahun 2009 Tentang Kekuasaan Kehakiman Pasal 1 Ayat 1.

Kata Kunci: iæin poligami, mendidik dan menolong calon istri

\section{Pendahuluan}

Agama Islam adalah agama yang sesuai dengan fitrah manusia dan selalu terjun dalam suatu realita, yang mendidik dan menjauhkan diri dari sikap teledor dan bermalas-malasan.1 Islam tidak mengizinkan asketisme dan mengorbankan kebutuhan-kebutuhan fisik yang alami dan fitrah, menurut Islam, segala segala naluri seksual atau bukan, harus dipenuhi dalam batas-batas yang wajar. Islam tidak membenarkan seseorang menuruti hawa nafsunya yang tak terpuaskan.2 Beristri itu adalah cara legal dan halal untuk menyalurkan hasrat seksual seseorang. Sebagaimana harta dan kekuatan, syahwat seks juga berpotensi menjebak kita untuk masuk kedalamnya, berburu kenikmatan, sehingga menjadi lupa diri.3

Pada kenyataannya, ada seorang pria yang beristeri hanya satu orang, ada yang secara diam-diam berhubungan dengan wanita lain. Perbuatan ini bukan hanya melanggar hak syariat, tetapi juga tata krama dan etika kepada masyarakat umum yang tidak pantas untuk dilakukan. Tidak ada satu pihakpun yang diuntungkan oleh perbuatan tersebut, baik yang berbuat maupun masyarakatnya. Hal ini yang bisa menghancurkan kesucian perkawinan, yang mana hubungan suami isteri tidak lebih dari sekedar hubungan seks tanpa kasih sayang.4

Kata-kata "poligami" terdiri dari kata 'poli" dan "gami". Secara etimologi, poli artinya "banyak", gami artinya "istri". Jadi poligami itu artinya beristri banyak. Secara terminologi, poligami yaitu 'seorang laki-laki mempunyai lebih dari satu istri". Atau, "seorang

1 Yusuf Qaradhawi, Hal wal Haram fil Islam, yang diterjemahkan oleh Tim Kuadran dengan judul Halal dan Haram (Bandung: Penerbit Jabal, 2007), 198.

2 Ibnu Mustafa, Perkawinan Mut'ah dalam Perspektif Hadist dan Tinjanan Masakini (Jakarta: Lentera, 1999), 70.

3 Agus Mustofa, Poligami Yunk! (Surabaya: Padra Press, 2010), 210.

4 Chuzaimah T. Yanggo dan Hafiz Anshory AZ, Problematika Hukum Islam dan

Kontemporer (Jakarta: Pustaka Firdaus, 1996), 105.

$2 \begin{aligned} & \text { AL-HUKAMA } \\ & \text { The Indonesian Journal of Islamic Family Law } \\ & \text { Volume 07, Nomor 02, Desember } 2017\end{aligned}$ 
laik-laki beristri lebih dari seorang, tetapi dibatasi paling banyak empat orang. 5

Undang-Undang Nomor 1 Tahun 1974 dan Peraturan Pemerintah Nomor 9 Tahun 1975 menggunakan istilah "Poligami" yang sudah popular dalam masyarakat. menurut undang-undang perkawinan ini adalah perkawinan yang bersifat monogami, namun demikian beristri lebih dari satu orang dapat dibenarkan asalkan tidak bertentangan dengan hukum agama yang dianutnya. Beristri lebih dari satu orang dapat dibenarkan asalkan dipenuhi beberapa alasan dan syarat tertentu yang ditetapkan oleh undang-undang. Perkawinan lebih dari satu orang dapat dilaksanakan apabila ada izin dari satu orang baru dilaksanakan apabila ada izin dari Pengadilan Agama terlebih dahulu. Dalam pasal 4 dan 5 Undang-Undang Nomor 1 Tahun 1974 tentang perkawinan dijelaskan bahwa seorang pria yang bermaksud kawin lebih dari satu orang harus ada alasanalasan yaitu (1) Istri tidak dapat menjalankan kewajibannya sebagai istri; (2) istri mendapat cacat badan atau penyakit yang tidak dapat disembuhkan; (3) istri tidak dapat melahirkan keturunan. Tidak dijelaskan secara rinci apakah ketentuan tersebut ini bersifat kumulatif atau alternatif. Oleh karena itu, penggunaan alasan-alasan tersebut diserahkan kepada hakim.6

Apabila alasan-alasan sebagaimana tersebut di atas sudah terpenuhi, maka Pengadilan Agama juga harus meneliti apakah ada atau tidaknya syarat-syarat tertentu secara kumulatif yaitu (1) persetujuan dari istri atau istri-istrinya, kalau ada harus diucapkan di muka majelis hakim; (2) kemampuan dari material dari orang yang bermaksud menikah lebih dari satu orang; dan (3) jaminan berlaku adil terhadap istri-istrinya apabila ia sudah menikah, jaminan berlaku adil ini dibuat dalam persidangan majelis hakim. Apabila syaratsyarat ini sudah terpenuhi secara kumulatif, maka barulah Pengadilan Agama memberi izin kepada pemohon untuk melaksanakan perkawinan lebih dari satu orang. Apabila perkawinan lebih dari satu orang tidak dilaksanakan sebagaimana ketentuan tersebut di atas, maka perkawinan tersebut tidak berdasarkan hukum

5 Abd. Rahman Ghazaly, Figh Munakahat (Bogor: Kencana, 2003), 129.

6 Abdul Manan, Aneka Masalab Hukum Perdata Islam di Indonesia..., 9-10. 
dan kepada pelakunya dapat dikenakan sanksi sebagaimana tersebut dalam pasal 44 dan 45 undang-undang perkawinan ini.7

Dalam hal istri tidak mau memberikan persetujuan, dan permohonan izin untuk beristri lebih dari satu orang berdasarkan salah satu alasan yang diatur dalam pasal 55 ayat (2) dan pasal 57, Pengadilan Agama dapat menetapkan tentang pemberian izin setelah memeriksa dan mendengar istri yang bersangkutan di persidangan Pengadilan Agama, dan terhadap penetapan ini istri atau suami dapat mengajukan banding atau kasasi. 8

Poligami atau perkawinan lebih dari satu orang merupakan suatu hal yang sangat ditakuti oleh setiap kaum wanita. Pelaksanaan poligami atau kawin lebih dari satu orang tanpa adanya peraturan untuk membatasinya secara ketat, maka akan menimbulkan hal-hal yang bersifat negatif dalam menegakkan rumah tangganya. Biasanya hubungan dengan istri muda (madunya istri tua) menjadi tegang, sementara itu anak-anak yang berlainan ibu itu menjurus kepada pertentangan yang membahayakan kelangsungan hidupnya. hal ini biasanya terjadi kalau ayah telah meninggal dunia. Agar hal-hal yang bersifat negatif itu tidak terjadi dalam rumah tangga orang-orang yang kawin lebih dari satu orang, maka undang-undang Perkawinan ini membatasinya secara ketat pelaksanaan perkawinan yang demikian itu, dengan mengantisipasi lebih awal membatasi kawin lebih dari satu orang itu dengan alasan-alasan dan syarat-syarat tertentu.

Undang-undang perkawinan memberikan suatu harapan bahwa perkawinan yang dilaksanakan itu betul-betul membawa manfaat kepada mereka yang melaksanakannya.9 Sebagaimana Allah SWT. Berfirman dalam Q.S. An-Nisa: 3:

"dan jikea kamu takut tidak akan dapat berlaku adil terbadap (hakhak) perempuan yang yatim (bilamana kamu mengawininya), maka kawiniah wanita-wanita (lain) yang kamu senangi; dua, tiga atau empat. Kemudian jika kamu takut tidak akan dapat berlaku adil, maka

7 Ibid.,

8 Idris Ramulyo, Hukum Perkawinan Islam (Jakarta: Bumi Aksara, 1999), 83.

9 Abdul Manan, Aneka Masalah Hukum Perdata Islam di Indonesia..., 10. 
kawininilah seseorang saja, atau budak-budak yang kamu miliki. Yang demikian itu lebih dekat kepada tidak berbuat aniaya."

Maksud ayat tersebut adalah jika seorang laki-laki merasa yaitu tidak dapat berbuat adil kepada anak-anak perempuan yatim, maka carilah perempuan lain. Pengertian semacam ini dalam ayat tersebut bukanlah sebagai hasil dari pemahaman secara tersirat, sebab para ulama sepakat bahwa siapa yang yakin dapat berbuat adil terhadap anak perempuan yatim, maka ia berhak untuk menikahi wanita lebih dari seorang. Sebaliknya, jika takut tidak dapat berbuat adil ia dibolehkan menikah dengan perempuan yang lain10

Meski telah disebutkan dalam undang-undang perkawinan No. 1 Tahun 1974 dan juga Kompilasi Hukum Islam (KHI) tentang syarat-syarat poligami baik yang alternatif maupun yang kumulatif diharuskan memenuhi persyaratan yang telah disebut di atas, akan tetapi terdapat realitas putusan tentang poligami yang tidak memenuhi persyaratan yang telah dicantumkan dalam undangundang tersebut. Salah satu penyebab apabila terjadi kurangnya salah satu syarat izin poligami maka seorang hakim harus bisa menolak apabila terjadi yang seperti itu. Seperti syarat dari alternatif alasanalasannya yaitu (1) Istri tidak dapat menjalankan kewajibannya sebagai istri; (2) istri mendapat cacat badan atau penyakit yang tidak dapat disembuhkan; (3) istri tidak dapat melahirkan keturunan. Terdapat juga syarat-syarat kumulatif yaitu (1) persetujuan dari istri atau istri-istrinya, kalau ada harus diucapkan di muka majelis hakim; (2) kemampuan dari material dari orang yang bermaksud menikah lebih dari satu orang; dan (3) jaminan berlaku adil terhadap istriistrinya. 11

Adapun terdapat di Pengadilan Agama Sidoarjo bahwa disana mengizinkan adanya poligami yang dengan alasan dikarenakan ingin mendidik dan menolong calon istri sesuai Sunah Nabi Muhammad SAW. menjadi hal yang baru dan hakim dinilai bersikap Contra Legem (tindakan hakim yang tidak sesuai dengan undang-undang yang berlaku).

10 Slamet Abidin dan Aminuddin, Fiqih Munakahat 1 Untuk Fakultas Syariah Komponen MKDK (Bandung: Pustaka Setia, 1999) 132.

11 Ibid., 


\section{Syarat-Syarat Poligami}

Ada yang perlu diperhatikan apabila hendak menikahi lebih dari seorang itu adalah sebuah pengecualian, karena itu disertai dengan alasan-alasan, syarat-syarat dan juga tujuan yang mendesak. Pembatasan-pembatasan itu antara lain adalah:12

1. Poligami tidak diperbolehkan menikahi seorang wanita lebih dari empat orang sebagaimana yang telah tercantum dalam alQuran, walaupun ada beberapa yang berpendapat diperbolehkan mengawinkan 9 orang, yaitu dengan menambahkan penjumlahan yang ada seperti dua ditambahkan tiga, ditambahkan empat dan hasilnya sembilan. Penasiran itu tidak benar adanya.

2. Sebagaimana dalam al-Quran adalah mampu berlaku adil kepada seluruh kelurganya terutama istri-istri serta anakanaknya. Namun apabila tidak sanggup melakukannya lebih baik tidak menikah lebih dari satu kali dan seterusnya.

3. Hendaknya apabila hendak ingin menikah lagi seharusnya adalah ada seorang wanita yang mempunyai seorang anak lagi yatim, supaya laki-laki yang hendak berpoligami tersebut dapat mengasuh anak tersebut. agar ia dapat berlaku adil terhadap apa yang ada di anak yatim tersebut baik anak yatim itu sendiri maupun dalam hartanya.

4. Wanita yang hendak dipoligami tidak boleh mempunyai suatu hubungan persaudaraan baik sedarah ataupun sepersusuan.

Tidak hanya memenuhi persyaratan-persyaratan yang telah dipaparkan diatas saja akan tetapi syarat-syarat ini juga harus dipenuhi.13 Ini telah tercantumkan dalam pasal 4 dan pasal 5 undang-undang perkawinan yang berbunyi:14

Pasal 4

(1) Dalam hal seorang suami akan beristri lebih dari seorang, sebagaimana tersebut dalam pasal 3 ayat 3 Undang-undang

12 Soemiyati, Hukum Perkawinan Islam...,76.

13 Ahmad Rofiq, Hukum Islam..., 172.

14 Team Prospect, Kumpulan Kitab Undnag-Undang Hukum KUH Perdata KUHP KUHAP (Jakarta: Wipress, 2008), 388.

\footnotetext{
$6 \begin{aligned} & \text { AL-HUKAMA } \\ & \text { The Indonesian Journal of Islamic Family Law } \\ & \text { Volume 07, Nomor 02, Desember } 2017\end{aligned}$
} 
ini, maka ia wajib mengajukan permohonan kepada pengadilan di daerah tempat tinggalnya.

(2) Pengadilan dimaksud dalam ayat (1) pasal ini hanya memberikan izin kepada seorang suami yang akan beristri lebih dari seorang apabila:

a. Istri tidak dapat menjalankan kewajibannya sebagai istri;

b. Istri mendapat cacat badan/atau penyakit yang tidak dapat disembuhkan.

c. Istri tidak dapat melahirkan keturunan.

Pasal 5

(1) Untuk dapat mengajukan permohonan kepada pengadilan, sebagaiana dimaksud dalam pasal 4 ayat (1) undangundang ini harus dipenuhi syarat-syarat sebagai berikut:

a. Adanya persetujuan dari isteri/isteri;

b. Adanya kepastian bahwa suami mampu menjamin keperluan-keperluan hidup isteri-isteri dan anak-anak mereka;

c. Adanya jaminan bahwa suami akan berlaku adil terhadap isteri-isteri dan anak-anak mereka.

(2) Persetujuan yang dimaksud pada ayat (1) huruf a pasal ini tidak diperlukan bagi seorang suami apabila isteri/isteriisterinya tidak mungkin dimintai persetujuannya dan tidak dapat menjadi pihak dalam perjanjian, atau apabila tidak ada kabar dari isterinya selama sekurang-kurangnya 2 (dua) tahun, atau Karena sebab-sebab lainnya yang perlu mendapat penilaian dari hakim pengadilan.

Terdapat juga peraturan dan persyaratan poligami selain terdapat dalam undang-undang perkawinan No. 1 Tahun 1974, yakni Kompilasi Hukum Islam (KHI) yang terdapat pada bagian IX dengan judul, "Beristri lebih dari satu orang" yang telah tercantum beberapa pasal, dimulai dari pasal 55 sampai dengan pasal 58. Yang berbunyi sebagai berikut:15

Pasal 55

15 Tim Permata Press, Kompilasi Hukum Islam (KHI) Hukum Perkawinan, Kewarisan, dan Perwakafan, 17. 
Muahammad Salim: Diterimanya Izin Poligami...

1. Beristri lebih dari satu orang pada waktu bersamaan, terbatas hanya sampai empat orang istri.

2. Syarat utama beristri lebih dari satu orang, suami harus mampu berlaku adil terhadap istri-istri dan anak-anaknya.

3. Apabila syarat utama yang disebut pada ayat (2) tidak mungkin dipenuhi, suami dilarang beristri lebih dari satu orang.

Pasal 56

1. Suami yang hendak beristri lebih dari satu orang harus mendapat izin dari Pengadilan Agama.

2. Pengajuan permohonan izin dimasukkan pada ayat 1 dilakukan menurut tat acara sebagaimana diatur dalam Bab VIII PP No. 9 Tahun 1975.

3. Perkawinan yang dilakukan dengan istri kedua, ketiga atau keempat tanpa izin dari Pengadilan Agama, tidak mempunyai kekuatan hukum.16

Pasal 57

Pengadilan Agama hanya memberikan izin kepada seorang suami yang akan beristri lebih dari seorang apabila:

a. Isteri tidak dapat menjalankan kewajiban sebagai isteri;

b. Isteri mendapat cacat badan atau peyakit yang tidak dapat disembuhkan;

c. Isteri tidak dapat melahirkan keturunan.

Pasal 58

(1) Selain syarat utama yang disebut pada pasal 55 ayat (2) maka untuk memperoleh izin pengadilan Agama, harus pula dipenuhi syarat-syarat yang ditentukan pada pasal 5 Undang-undang No. 1 Tahun 1974 yaitu:

a. Adanya persetujuan istri;

b. Adanya kepastian bahwa suami mampu menjamin keperluan hidup isteri-isteri dan anak-anak mereka.

(2) Dengan tidak mengurangi ketentuan pasal 41 huruf b Peraturan Pemerintah No. 9 Tahun 1975, persetujuan istri atau istri-istri dapat diberikan secara tertulis atau dengan lisan, tetapi sekalipun telah ada persetujuan tertulis,

16 Ibid.,

$8 \begin{aligned} & \text { AL-HUKAMA } \\ & \text { The Indonesian Journal of Islamic Family Law } \\ & \text { Volume 07, Nomor 02, Desember } 2017\end{aligned}$ 
persetujuan ini dipertegas dengan persetujuan lisan istri pada sidang Pengadilan Agama.

Persetujuan dimaksud pada ayat (1) huruf a tidak diperlukanbagi seorang suami apabila isteri atau isteri-isterinya tidak mungkin dimintai persetujuannya dan tidak dapat menjadi pihak dalam perjanjian atau apabila tidak ada kabar dari isteri atau isteriisterinya sekurang-kurangnya 2 tahun atau Karena sebab lain yang perlu mendapatkan penilaian hakim

\section{Prosedur Poligami}

Melakukan sebuah pernikahan pasti memiliki aturan dan juga prosedur yang harus dilalui, namun sama halnya juga dengan melakukan poligami. Negara juga punya prosedur-prosedur yang harus dilakukan oleh para pihak bila ingin melakukan poligami sesuai dengan aturan-aturan yang telah berlaku di Indonesia. Aturan dalam melakukan prosedur poligami itu telah diatur dan bisa diihat pada Peraturan Pemerintah No. 9 Tahun 1975. Yang terdapat dalam pasal 40 yang berbunyi:17Apabila seorang suami bermaksud untuk beristri lebih dari seorang maka ia wajib mengajukan permohonan secara tertulis kepada Pengadilan. Tugas pengadilan juga telah diatur dalam pasal 41 Peraturan Pemerintah Tahun 1975 yang bunyinya sebagai berikut: 18

Pengadilan kemudian memeriksa mengenai:

1. Ada atau tidaknya alasan yang memungkinkan seorang suami kawin lagi.

2. Ada atau tidak adanya persetujuan dari istri, baik persetujuan lisan maupun tertulis, apabila persetujuan itu merupakan persetujuan lisan, persetujuan itu harus diucapkan di depan sidang pengadilan.

3. Ada atau tidak adanya kemampuan suami untuk menjamin keperluan hidup istri-istri dan anak-anak, dengan memperlihatkan:

i. Surat keterangan mengenai penghasilan suami yang ditandatangani oleh bendahara tempat kerja; atau

17 Ibid., 410.

18 Ibid., 
ii. Surat keterangan pajak penghasilan; atau

iii. Surat keterangan lain yang dapat diterima oleh pengadilan

4. Ada atau tidak adanya jaminan bahwa suami akan berlaku adil terhadap istri-istri dan anak-anak mereka dengan pernyataan atau janji dari suami yang dibuat dalam bentuk yang ditetapkan untuk itu.

Pasal selanjutnya yakni yang terletak pada pasal 43 yang telah menerangkan bahwasanya pengadilan harus memanggil pihak istri untuk memberikan keterangan beserta kesaksiannya dalam persidangan perkara poligami agar tidak hanya secara tertulis namun juga secara lisan dapat diakui pengakuannya. Akan tetapi pasal ini juga memberikan waktu kepada pengadilan selama kurang lebih 30 hari atau satu bulan untuk memeriksa, mempertimbangkan juga memutuskan permohonan poligami ini setelah suami mampu melengkapi semua persyaratan yang ada.19

Peraturan Pemerintah No. 9 Tahun 1975 pada pasal 43 menyatakan bahwa Pengadilan Agama memiliki kewenangan untuk memberikan putusan kepada pemohon yang hendak melakukan poligami sesuai dengan peraturan yang ada. Pasal 43 yang berbunyi:20Apabila pengadilan berpendapat bahwa cukup alasan bagi pemohon untuk beristri lebih dari seorang, maka pengadilan memberikan putusannya yang berupa izin untuk beristri lebih dari seorang.

Undang-undang ini sangat memperhatikan dalam seseorang yang hendak izin poligami, karena izin poligami ini sangat diperhatikan bahwa Pegawai Pencatat Nikah tidak diperbolehkan melakukan pencatatan nikah sebelum adanya keterangan izin poligami dari pengadilan itu sendiri, sebagaimana telah diatur dalam pasal selanjutnya yakni Peraturan Pemerintah No. 9 Tahun 1975 pada pasal 44.

Hal isteri tidak mau memberikan persetujuan, dan permohonan izin untuk beristeri lebih dari satu orang berdasarkan atas salah satu alasan yang diatur dalam pasal 55 ayat (2) dan 57 ,

19 Amiur Nuruddin, Azhari Akmal Tarigan, Hukum Perdata Islam di Indonesia (Jakarta: Kencana, 2004), 165.

20 Team Prospect, Kumpulan Kitab Undang-Undang..., 410.

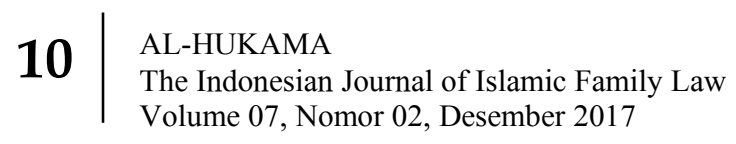


Pengadilan Agama dapat menetapkan pemberian izin setelah memeriksa dan mendengar isteri yang bersangkutan dipersidangan Pengadilan Agama, dan terhadap penetapan ini isteri atau suami dapat mengajukan banding atau kasasi (ps. 59 KHI). Apabila keputusan hukum yang mempunyai kekuatan hukum tetap, izin pengadilan tidak diperoleh, maka menurut ketentuan pasal $44 \mathrm{PP}$ No. 9 Tahun 1975, Pegawai Pencatat dilarang untuk melakukan pencatatan perkawinan seorang suami yang akan beristeri lebih dari seorang sebelum adanya izin pengadilan seperti yang dimaksud dalam pasal 43 (PP No. 9 Tahun 1975).21

\section{Deskripsi Perkara Diterimanya Izin Poligami Karena Ingin Mendidik dan Menolong Calon Istri Sesuai Dengan Sunah Nabi Muhammad SAW. di Pengadilan Agama (PA) Sidoarjo}

Pada tanggal 30 Juni 2015 Pemohon mengajukan surat permohonan izin poligami di kepaniteraan Pengadilan Agama Sidoarjo dengan Nomor Putusan 1913/Pdt.G/PA.Sda. dengan uraian perkara sebagai berikut:22

Bahwa dalam putusan pengadilan tersebut telah menjelaskan bahwasanya antara Pemohon atau suami dan juga Termohon atau Istri ini sudah lama menjalin sebuah pernikahan yang cukup lama yang tepatnya terletak pada tanggal 15 Nopember 1996. Pernikahan tersebut telah dilakukan dengan sah menurut agama maupun negara yakni dengan cara melakukannya di Kantor Urusan Agama di kecamatan masing-masing yang sesuai dengan tempat tinggalnya di kota Sidoarjo. Selama menjalin pernikahan tersebut pasangan ini telah dikarunai keturunan sebanyak 4 orang anak. Anak kandung pertama telah berusia tujuh belas tahun, anak kandung kedua telah berusia tiga belas tahun, anak kandung ketiga telah berusia tujuh tahun, adapaun anak kandung yang terakhir berusia dua setengah tahun. Beberapa anak tersebut semuanya diasuh dan dididik oleh keduanya secara bersama-sama dalam satu rumah.

Setelah itu Pemohon ini mempunyai niat untuk menikah lagi dengan seorang wanita yang akan dijadikannya sebagai calon istri keduanya. Wanita ini juga bertempat tinggal di kota Sidoarjo dimana

21 Ahmad Rofiq, Hukum Islam..., 175.

22 Putusan Nomor 1913/Pdt.G/2015/PA.Sda. 
tempat tinggal Pemohon dan juga Termohon ini menetap. Wanita ini juga adalah mahasiswi Pemohon sendiri. dan Pemohon itu adalah dosennya dari perguruan tinggi ditempat ia menuntut ilmu. Namun status dari wanita ini adalah janda cerai. Pemohon dan wanita tersebut telah mengenal antara satu dengan yang lainnya telah cukup lama sekitar kurang lebih tiga tahun empat bulan, Tertanggal pada 20 Februari 2012. Selama menjalani perkenalan yang cukup lama itu maka keduanya ini setuju memutuskan untuk melanjutkan hubungan perkawinan yang sah dengan alasan Pemohon yakni ingin menolong dan membantu calon istri sesuai dengan sunah Nabi Muhammad SAW.23

Adanya niat dari Pemohon itu telah diketahui oleh istrinya Pemohon atau Termohon. Termohon ini pun menyetujui rela dan ikhlas apabila suaminya/Pemohon ini menikah lagi dengan wanita tersebut. keduanya juga baik Pemohon dan wanita tersebut tidaklah memiliki hubungan darah kekeluargaan baik dari segi sepersusuan ataupun yang lainnya. Keduanya ini tidak ada hubungan kekeluargaan, maka keduanya ini diperkenankan dan diperbolehkan untuk melakukan sebuah pernikahan baik dipandang dari segi agama maupun peraturan yang ada yakni dalam undang-undang yang berlaku di Indonesia. Namun bukan hanya dari situ saja akan tetapi juga dilihat dari penghasilan Pemohon yang lumayan cukup besar penghasilannya yakni sekitar rata-rata Rp. 10.000.000,-. Pemohon dapat memenuhi nafkah kebutuhan secara keseluruhan baik secara lahir maupun batin. Pemohon juga menyatakan bahwa ia mampu untuk berlaku adil untuk keluarganya baik dari istri-istri dan juga anak-anaknya. 24

Antara Pemohon dan juga Termohon ini telah memiliki harta bersama selama pernikahan itu berlangsung baik harta itu bergerak maupun yang tidak bergerak yang selama perkawinan telah dikumpulkan secara bersama-sama. maka dari itu calon istri kedua tersebut menyatakan tidak akan menggangu dan mengambil atau yang lainnya terhadap harta bersama milik keduanya baik Pemohon ataupun Termohon. Setelah menyampaikan pemaparan diatas tadi

23 Ibid.,

24 Ibid., 
maka Pemohon menginginkan Permohonannya ini dikabulkan/diterima untuk menikah lagi dengan wanita tersebut. namun apabila dari permohonan ini pengadilan khususnya para hakim mempunyai pendapat yang berbeda dengan Pemohon, maka mohon untuk memutuskan perkara ini dengan seadil-adilnya sesuai kadar dan ketentuan yang ada.

\section{Dasar Pertimbangan Hakim}

Menurut hakim Pengadilan Agama Sidoarjo, yakni hakim memutuskan perkara dalam izin poligami bahwa hakim tidak melihat segala alasan apapun yang diutarakan oleh pemohon baik karena ingin mendidik dan menolong calon istri sesuai Sunah Nabi Muhammad SAW. ataupun yang lainnya. Akan tetapi yang terutama yang menjadi dasar hukum hakim adalah tetap mengacu pada ketentuan pasal 5 ayat (1) Undang-undang No, 1 Tahun 1974 Tentang Perkawinan yang melihat persyaratan izin poligami itu sendiri yakni sudah adanya persetujuan dari istri/istri. Bahwa di depan persidangan Termohon telah memberikan persetujan secara lisan dikuatkan dengan adanya bukti P.4, karenanya sebagai bukti bahwa Termohon tidak keberatan. Walaupun hakim mengabaikan persyaratan poligami yang terdapat ketentuan dalam pasal 4 ayat (2) UU. No. 1 Tahun 1974 yang merupakan syarat fakultatif bahwa telah terbukti bahwa telah menjalankannya secara keseluruhan, sehingga syarat fakultatif tersebut tidak terpenuhi.25

Hal ini hakim berpandangan bahwa bahwa apabila syarat izin poligami terutama sudah mendapatkan izin dari istri pertama maka itu sudah bisa untuk mengabulkannya walaupun aspek lain dari persyaratan fakultatif tidak terpenuhi. Menurutnya poligami itu boleh yang sesuai dengan undang-undang yakni sudah mendapatkan dari izin istri Pemohon, dan disamping itu adil juga harus dipenuhi karena dalam Al-Quran orang berpoligami syarat utamanya adalah keadilan. Maka apabila keduanya ini telah terpenuhi maka ini sudah bisa diputuskan dan juga diterima oleh hakim untuk mengizinkannya berpoligami. Dan juga hakim mempertimbangkan bahwa kehendak pemohon untuk melakukan poligami tentu akan

25 Hj. Siti Aisyah, S.Ag, M.HP, Hakim Pengadilan Agama Sidoarjo, Wawancara, Sidoarjo, 09 April 2017 
menanggung mudarat (resiko) bahkan dampak negatif, namun hakim menilai bahwa resiko yang dihadapi oleh Pemohon dan Termohon lebih besar jika pemohon tidak diizinkan melakukan poligami dan juga melihat maslahah dan juga mudhorotnya26

Menurut hakim Pengadilan Agama Sidoarjo yang lain yaitu Siti Aisyah, S.Ag., M.H mengatakan bahwa:

"jadi gini hakim itu kan mempertimbangkan adalah untuk mencari kebenaran. Seperti istri bilang suami saya suka memukul dll, akan tetapi ketika dipersidangan tidak terbukti dan juga saksi-saksi tidak ada yang tahu, ternyata hanya masalah nafkah saja. jadi itu fakta-fakta yang ada didalam persidangan itu yang diambil yang dipertimbangkan." Begitu tuturnya.

Melihat dari alasan itu bahwa didalam undang-undang memang tidak ada. Menurut undang-undang itu sudah dijelaskan ada dipasal 4 dan 5 Undang-undang No. 1 Tahun 1974 dan PP No. 9 Tahun 1975 pasal 41 itu ada syarat-syarat alternatif dan juga syarat-syarat kumulatif kalau itu sudah dibuktikan ada dalam persidangan baik itu secara lisan maupun secara tertulis terbukti itu didalam undangundang ada itu bisa dijadikan pertimbangkan. Jadi kebenaran formilnya yang dicari. juga apabila dalam persyaratan alternatif tidak ada maka cari persyaratan yang dikumulatif. beliau juga berpendapat bahwa boleh mengabaikan pasal 4 yakni syarat-syarat alternatif. melihat pasal selanjutnya yang terdapat dalam pasal 5 ayat 1 , yang lebih penting itu adalah persyaratan adanya persetujuan dari istriistri, juga adanya pernyataan suami mampu berlaku adil itu dibuktikan dengan mempunyai harta benda apa saja dan mempunyai penghasilan berapa, dari situ bisa dipertimbangkan bahwa dia mampu bahwa suami ini untuk beristri lebih dari seorang. dari situ bisa dilihat bisa menghidupi dan juga menafkahi istri-istrinya dan juga anak-anaknya.27 Bahwa si calon istri ini telah diberlakukan secara keras dan semenang-menangnya oleh mantan suaminya dulu. Bahwa disering dipukuli disakiti dan lain-lain sebagainya. Sehingga membuatnya trauma dan terganggu mentalnya. Apabila tidak dikabulkan permohonannya maka ditakutkan terjadi keburukan

26 Ibid.,

27 Siti Aisyah, S.Ag, M.H, Hakim Pengadilan Agama Sidoarjo, Wawancara, Sidoarjo, 27 April 2017. 
yang lebih besar yakni bisa saja si calon istri kedua ini malah ingin bunuh diri dan lain sebagainya karena tidak ada yang mengayomi dan menjaga baik dari segi mental maupun lahiriahnya.

Beliau juga telah menceritakan sedikit kronologinya:

"Dan itu kasusnya istri yang dipoligami itu sudah bersuami tetapi bercerai dengan suaminya yang pertama dia itu sering di KDRT jadi kondisinya itu stress dan dia melanjutkan kuliah kebetulan bapak ini ikut mengajar menjadi mahasiswanya begitu, mungkin sering curhat dan akhirnya timbul iba" begitu kata hakim Pengadilan Agama yang memutuskan putusan poligami tersebut.

\section{Putusan Tentang Izin Poligami}

Selain adanya bukti-bukti secara tertulis maka diperlukan pula bukti-bukti secara lisan dan salah satunya adalah menghadirkan para saksi oleh Pemohon apakah informasi dan data itu benar adanya yang dimintai keterangan dari saksi-saksi tersebut. dan terdapat 2 saksi yang dihadirkan dalam persidangan yakni:28

Saksi yang pertama ini adalah dari saudaranya sendiri dari Pemohon yakni dia adalah keponakannya yang juga bertempat tinggal di kota Sidorajo. saksi ini telah berusia tiga puluh tahun dan juga agamanya sama dengan Pemohon yakni agama Islam. Saksi ini dimintai sumpah sebelum menerangkan keterangan yang sebenarbenarnya di depan sidang majelis hakim. Saksi telah mengetahui cukup lama hubungan antara Pemohon dan Termohon ini sebagai pasangan suami dan istri sejak melangsungkan pernikahan tertanggal 15 Nopember 1996. Tempat tinggal antara Pemohon dan juga Termohon ini terletak di kota Sidoarjo. Setelah melangsungkan pernikahan yang cukup lama pasangan antara Pemohon dan juga Termohon ini telah dikaruniai empat orang anak. Di samping saksi mengetahui antara keduanya ini telah mempunyai keturunan, saksi juga telah mengetahui bahwa ada niat dari Pemohon ini untuk melakukan poligami terhadap orang yang sudah cukup lama yang telah kenal dengannya. Yakni dengan seorang mahasiswinya sendiri yang telah berumur empat puluh tiga tahun yang telah berstatus sebagai seorang janda cerai. Antara keduanya ini telah saling mengenal cukup lama sekitar tiga tahun empat bulan. Setelah

28 Putusan Pengadilan..., 9. 
mengenal selama itu keduanya ini bersepakat untuk menjalin hubungan ke jenjang yang lebih serius dengan melakukan pernikahan yang sah. Adapun alasan dari Pemohon sendiri dihadapan majelis hakim adalah ingin mendidik dan menolong calon istri sesuai dengan sunah Nabi Muhammad SAW. namun sebelum itu rencana itu telah dirapatkan ke keluarga terutama dengan istri pertama Pemohon yakni Termohon. memang antara keduanya ini tidak mempunyai hubungan keluarga sama sekali baik dilihat dari segi sepersusuan, mahram ataupun yang lainnya. Maka dari itu pernikahan ini diperkenankan dan juga diperbolehkan tidak ada larangan maupun halangan untuk melakukan sebuah pernikahan baik itu dilihat dari sisi agama maupun dari sisi pandang peraturan perundang-undangan yang berlaku di Indonesia. Bahkan saksi juga mengetahui Pemohon ini mempunyai penghasilan yang cukup banyak. Rata-rata penghasilannya itu sekitar Rp. 10.000.000,-. Sehingga dengan penghasilan sebesar itu mampu menjamin akan kebutuhan menafkahi untuk kelurganya baik untuk istri-istrinya maupun untuk anak-anaknya. Dilihat dari profesi Pemohon ini sebagai seorang penceramah agama maka saksi memandang Pemohon ini adalah orang yang bertingkah laku dan akhlak yang baik.

Saksi yang kedua ini, saksi adalah termasuk dari salah satu keluarga dari Pemohon yakni kakak kandungnya sendiri. Usia dari saksi yang kedua ini sudah cukup tua yang telah berusia kurang lebih menginjak umur lima puluh empat tahun. Agamanya juga tidak berbeda dengan Pemohon yakni beragama Islam. Adapun profesi dari saksi yang kedua ini adalah sebagai seorang guru sekolah. Tempat tinggalnya juga tidak jauh dari Pemohon satu kota juga kota Sidoarjo. Saksi ini dimintai kesediaannya untuk disumpah di depan sidang majelis hakim sebelum memberikan keterangannya dengan sebenar-benarnya. Saksi juga telah mengetahui bahwa Pemohon ini sudah cukup lama melangsungkan perkawinan dengan Termohon yang telah berlangung sejak tertanggal 15 Nopember 1996. Selama menjalin hubungan pernikahan tersebut antara Pemohon dan juga Termohon telah dikaruniai keturunan sebanyak empat orang anak. Saksi juga tahu bahwa Pemohon ini mempunyai suatu niat yakni ingin menikah lagi dengan seorang wanita yang tak lain adalah 
mahasiswinya Pemohon sendiri. yang telah berusia empat puluh tiga tahun. Agamanya juga sama yakni Islam. Status wanita ini dia telah menjadi seorang janda cerai. Antara Pemohon dan juga calon istri kedua ini sudah cukup lama mengenal antara satu dengan yang lainnya kurang lebih sudah selama tiga tahun empat bulan. Setelah melalui perkenalan yang cukup lama itu keduanya setuju dan juga sepakat untuk menjalin hubungan yang lebih serius dengan melakukan pernikahan. Adapun alasan yang digunakan pemohon adalah ingin mendidik dan menolong calon istri sesuai dengan sunah Nabi Muhammad SAW. bukan hanya itu saja saksi juga mendengar sendiri bahwa Termohon ini ikhlas dan rela bila suaminya menikah lagi dengan wanita tersebut. Saksi juga melihat dan mengetahui bahwa antara Pemohon dan juga wanita tersebut tidaklah mempunyai suatu hubungan keluarga baik dari segi darah, sepersusuan maupun yang lainnya, Sehingga tidak ada halangan dan juga larangan untuk keduanya melakukan sebuah pernikahan yang sah baik dilihat dari segi agama maupun dipandang dari segi peraturan perundang-undangan yang berlaku di Indonesia. Pemohon ini juga berprofesi sebagai seorang guru agama yang penghasilannya lumayan besar kurang lebih sekitar Rp. 10.000.000,. Penghasilan sebesar ini maka mampu Pemohon untuk menafkahi keluarganya terutama untuk istri-istrinya dan juga anak-anaknya.

Termohon ini adalah seorang istri dari seorang Pemohon yang berstatus sebagai suaminya. Termohon ini sudah berusia lebih dari tiga puluh tahun dan tepatnya pada umur tiga puluh tujuh tahun. Hal agama juga Termohon ini sama yakni beragama Islam. Antara Pemohon dan Termohon ini sudah menjalin hubungan pernikahan yang cukup lama yakni semenjak tertanggal pada 15 Nopember 1996. Selama menjalin hubungan pernikahan tersebut pasangan ini telah dikaruniai keturunan sebanyak 4 orang anak. Termohon juga sudah tahu niat dari Pemohon, bahwa Pemohon ini hendak menikah lagi dengan seorang wanita dimana wanita ini adalah mahasiswinya Pemohon sendiri. Wanita ini juga telah berstatus sebagai seorang janda cerai. Mereka juga sudah mengenal lama antara satu dengan yang lain yakni sudah kurang lebih tiga tahun empat bulan. Setelah mengenal satu dengan yang lain selama itu, maka mereka memutuskan menjalin hubungan yang lebih serius dengan 
melakukan sebuah pernikahan yang sah. Istri pertama ini setelah mengetahui hal tersebut dia rela dan ikhlas untuk mengizinkan suaminya menikah lagi dengan wanita itu yakni yang nantinya akan menjadi calon istri kedua Pemohon. Istri pertama pemohonn ini juga tahu bahwa antara Pemohon dan juga wanita tersebut tidak mempunyai sebuah hubungan kekeluargaan darah ataupun sepersusuan dan lainnya, Sehingga tidak ada larangan dan juga halangan apabila mereka berdua ini melakukan sebuah pernikahan yang sah baik dilihat dari segi agama maupun dari peraturan yang ada yakni undang-undang yang berlaku di Indonesia. Memang penghasilan dari Pemohon ini lumayan besar yakni sebesar Rp. 10.000.000,-. Maka dengan penghasilan yang cukup besar ini maka Termohon yakin bahwa Pemohon ini bisa memenuhi kebutuhan nafkah dengan adil untuk istri-istri dan juga anak-anaknya baik dari segi materiil maupun non materiil.29

Hasil putusan

Beberapa alat-alat bukti yang ada baik dari barang bukti yang secara tertulis maupun yang secara lisan, dengan pertimbanganpertimbangan hakim yang ada dan juga melihat fakta-fakta yang ada dalam persidangan maka para majelis hakim telah memutuskan dan juga menetapkan bahwa majelis hakim menerima permohonan Pemohon dengan mengizinkannya untuk menikah lagi dengan wanita tersebut. 30

Adanya putusan tersebut yang telah dihadiri oleh Pemohon yakni seorang suami dengan Termohon yakni istri dari Pemohon dan telah datang juga calon istri kedua di dalam persidangan poligami ini. Persidangan ini telah ditetapkan dan telah diputuskan pada hari Senin tertanggal 07 September 2015 yang terletak tepatnya pada tanggal 22 Dzulqaidah 1437 Hijriyah. Diketuai Oleh Siti Aisyah beserta hakim-hakim anggota lainnya dan juga panitera pengganti di Pengadilan Agama Sidoarjo.

\section{Analisis Terhadap Dasar Pertimbangan Hakim Tentang Izin Poligami Di Pengadilan Agama Sidoarjo}

29 Ibid., 4.

30 Ibid., 21. 
Pada putusan majelis hakim Pengadilan Agama Sidoarjo dengan Nomor Perkara: 1913/Pdt.G/PA.Sda tentang izin poligami karena ingin mendidik dan menolong calon istri sesuai dengan sunah Nabi Muhammad SAW. adalah sebagai alasan dan juga tujuan oleh Pemohon untuk mengajukan izin poligami di pengadilan. Bukan hanya karena alasan ingin mendidik dan menolong calon istri sesuai dengan sunah Nabi Muhammad SAW. tetapi juga karena alasan bahwa calon istri ini memiliki trauma terhadap perkawinan yang lalu, sebagaimana mantan suaminya dulu membuatnya gelisah dan takut sehingga diperlukannya pertolongan untuk mendidiknya baik secara mental itu sendiri sekaligus secara lahirnya juga.

Bahwa Pengadilan Agama khususnya majelis hakim pasti orang memiliki tujuan untuk datang adalah untuk mencari keadilan itu sendiri. baik kemanfaatan hukumnya maupun adanya kepastian hukum bahwa statusnya jelas dan lain-lain. Selain terdapat keinganan yang dibutuhkan utama adalah keadilan, namun ada juga yang ingin mendapatkan kepastian statusnya tersebut. sehingga tidak ada kerugian yang ditimbulkan maupun kesalahpahaman antara suami, istri dan juga calon istri kedua ini. Pada lapangan prakteknya bahwa apabila seseorang yang hendak menikah kembali lebih dari satu kali, maka ia diwajibakan dan diharuskan untuk memenuhi ketentuanketentuan yang ada baik peraturan itu yang terdapat didalam agama atau syariat Islam maupun peraturan perundang-undangan yang telah tertulis yang telah dibuat oleh pemerintah negara. Namun didalam peraturan negara tersebut atau yang disebut undang-undang telah menyatakan dan juga tertulis bahwa siapapun yang ingin melangsungkan sebuah perkawinan hendaknya memberitahukan keinginan itu untuk dilaksanakan di pegawai pencatat nikah atau di Kantor Urusan Agama bagi orang muslim ataupun di Catatan Sipil bagi orang-orang non-muslim.

Pada permohonan yang telah diajukan Pemohon ke pengadilan tersebut, telah terbukti bahwa istri pertama ini telah memenuhi kewajibannya sebagai seorang istri, istri ini juga telah mempunyai keturunan maupun istri ini tidak mempunyai penyakit yang parah sehingga dia dianggap masih mampu melayani suaminya tersebut itu dengan sebaik-baiknya. Para majelis hakim juga melihat bagaimana situasi dan kondisi si calon istri kedua tersebut. Bahwa calon istri 
kedua ini memiliki trauma yang pernah terjadi pada dirinya. Ketika ia menikah dengan mantan suaminya yang dulu, ia disiksa dan terjadi kekerasan dalam rumah tangganya, sehingga apabila tidak ditolong oleh calon suaminya ini ditakutkan keadaannya makin parah dan tidak bisa disembuhkan selama hidupnya. Maka majelis hakim untuk memperkuat itu maka menggunakan sebuah dalil yang berbunyi:

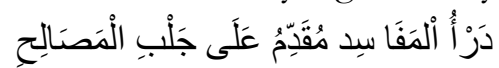

Artinya : Menolak atau mengbindari mafsadat harus didabulukan dari pada menarik maslahat.

Itu adalah sebagai dasar hukum yang dicantumkan oleh hakim, karena yang menjadi tolak ukur utamanya adalah memenuhi kemaslahatan yang ada dan menghindari sejauh-jauhnya kemadaratan yang ada, selain dengan adanya dalil tersebut, bahwa majelis hakim juga mempunyai pandangan dan landasan lain yakni hakim telah mempertimbangkan dengan bukti-bukti yang ada dan juga telah memenuhi persyaratan bahwa suami dapat memperlakukan istri-istrinya dengan adil baik dari segi lahir maupun batin, materiil maupun non-materiil. Dimaksud adil disini adalah seperti bahwa dia mampu memenuhi segala kebutuhan untuk istrinya yakni dalam masalah makan, minum, pakaian, tempat tinggal, bermalam beserta nafkah. dan bukti tersebut dilampirkan dengan surat bukti mampu berlaku adil serta adanya izin istri pertama Pemohon yang menyatakan tidak keberatan untuk dinikahkan lagi dengan seorang wanita baik pernyataan itu secara lisan maupun secara tertulis. Sebagaimana yang telah tercantum syarat-syarat yang ditentukan yang terdapat dalam pasal 5 ayat (1) Undang-Undang Nomor 1 tahun 1974, Jo. Pasal 55 ayat (2), pasal 57 dan 58 ayat (2) Kompilasi Hukum Islam telah terpenuhi dan permohonan izin poligami tersebut. sebagaimana menurut para majelis hakim bahwa itu baru bisa diterima atau dikabulkan permohonannya itu.

Adapula dari beberapa berbeda sudut pandang yang salah satunya adalah dari pemikiran legisme. Dimaksud dari legisme itu sendiri adalah bahwa hakim dalam memutuskan segala perkara itu hanya menggunakan satu sumber dalam mempertimbangkan dan juga memutuskan perkara tersebut dan sumbernya hanya berasal 
dari undang-undang saja tanpa melihat sumber-sumber yang lain dalam memutuskan dan juga mempertimbangkan suatu perkara tersebut. Apabila ada sebuah peraturan yang mencantumkan harus ada peraturan yang sesuai dengan pasal 3 dan juga 4 dalam undangundang perkawinan atau peraturan yang lain sebagainya maka ditakutkan dan juga dikhawatirkan lebih banyak kejelekannya daripada kebaikan-kebaikannya.

Melihat dan juga mengamati apa yang ditelusuri oleh penulis, maka penulis juga sependapat dengan dasar-dasar dan juga pertimbangan-pertimbangan yang dilakukan oleh para majelis hakim, karena hakim disini harus bersifat aktif dalam mencari info/berita dan harus menggali hukum sedalam-dalamnya dan juga seluas-luasnya dalam mewujudkan kecerminan keadilan yang seadiladilnya dalam melakukan proses hukum yang berlangsung sehingga hukum itu bisa ditegakkan. Aparat hukum haruslah berlaku adil dengan memberikan dan juga mewujudkan apa yang sudah menjadi haknya.

Tidak hanya itu saja akan tetapi aparat hukum juga harus menggunakan asas-asas yang telah dicantumkan, salah satunya adalah menerapkan asas equality before the law. Dimaksud dengan equality before the law adalah bahwa semua orang berhak memliki kedudukan yang sama dalam menjalankan proses hukum yang sedang berlangsung tersebut. Sebagaimana hal ini telah tercantum dan juga telah tertulis didalam Undang-Undang Dasar 1945 yang telah terdapat dalam pasal 27 ayat 1 . Disini mengatur bahwa setiap warga negara wajib di lindungi untuk perlindungan terhadap hakhak asasi sebagai warga negara Indonesia dalam menegakkan keadilan hukum yang secara merata sebelum adanya status putusan bersalah dari para majelis hakim pengadilan.

\section{Analisis Yuridis Terhadap Putusan Izin Poligami Pada Putusan No: 1913/Pdt.G/2015/PA.Sda.}

Indonesia adalah negara hukum dimana hampir semuanya diatur oleh undang-undang, termasuk salah satunya dalam hal perkawinan. Hukum perkawinan yang mengatur tata cara, syaratsyarat dan juga rukun-rukunnya perkawinan agar sah dan diakui perkawinan itu dalam agama maupun dalam negara. Namun tidak hanya sampai disitu saja akan tetapi ada juga peraturan yang 
mengenai tentang perkawinan yang melebihi dari seseorang istri yang biasa disebut dengan poligami. Poligami juga diatur oleh pemerintah dalam Undang-undang Perkawinan No. 1 Tahun 1974, Kompilasi Hukum Islam dan juga dalam Peraturan Pemerintah No. 9 Tahun 1975.

Setelah mendengar, melihat dan juga mempelajari pertimbangan-pertimbangan hukum oleh hakim yang memutuskan perkara persidangan tentang diterimanya izin poligami karena ingin mendidik dan menolong calon istri sesuai sunah Nabi Muhammad SAW. No.1913/Pdt.G/2015/PA.Sda, penulis mendeskripsikan bahwasanya dalam berpoligami sebagaimana telah diatur dalam negara yang telah berdasarkan Undang-Undang Nomor 1 Tahun 1974 harus adanya kewajiban suami dalam mengajukan permohonan izin poligami, perlunya untuk melengkapi persyaratanpersyaratan yang telah diatur yakni perlu melengkapi syarat-syarat kumulatif, namun selain itu juga suami dalam mengajukan izin poligami harus juga memenuhi semua persyaratan yang bersifat alternatif sebagaimana yang telah diatur dan ditentukan dalam Undang-Undang Nomor 1 Tahun 1974 dan terdapat juga dalam KHI (Kompilasi Hukum Islam) yang telah diatur dalam Bab IX Tentang Beristri lebih dari seorang yang juga menjelaskan persyaratan-persyaratan seseorang untuk beristri lebih dari seorang hampir sama saja dengan Undang-undang Perkawinan No. 1 Tahun 1974 akan tetapi dalam KHI terdapat dalam Pasal 57 yakni apabila istri tidak dapat menjalankan kewajibannya sebagai seorang istri, mempunyai cacat lahir atau bathin dalam tubuhnya dan juga seorang istri itu tidak dapat melahirkan keturunan untuk suaminya. Sebagaimana hal ini telah tercantum dalam pasal 4 ayat (1) Undangundang Perkawinan No. 1 Tahun 1974 sebagai berikut:31 istri tidak dapat menjalankan kewajibannya sebagai seorang istri, istri mendapat cacat badan atau penyakit yang tidak dapat disembuhkan, istri tidak dapat melahirkan keturunan.

Diantara syarat-syarat alternatif tersebut haruslah terpenuhi salah satu di antara tiga syarat tersebut oleh Pemohon dalam mengajukan permohanan izin poligami. Selain itu juga dalam hal

31 Team Prospect, Kumpulan Kitab Undang-Undang Hukum KUH Perdata KUHP KUHAP, (Jakarta: Wipress, 2008), 388. 
mengajukan permohonan izin poligami seorang suami harus pula memenuhi ketentuan seluruh syarat kumulatif sebagaimana yang ditelah tercantum dalam Undang-Undang Nomor 1 Tahun 1974 yakni adanya persetujuan dari seorang istri, kemampuan dalam menjamin segala kebutuhan kebutuhan hidup seorang istri maupun untuk anak-anaknya, hal ini telah tercantum dalam Pasal 5 ayat (1). Terdapat juga dalam KHI (Kompilasi Hukum Islam) yang tercantum dalam pasal 58 ayat 2 yang berbunyi sebagai berikut:32 adanya persetujuan dari istri/istri-istri, adanya kepastian bahwa suami mampu menjamin keperluan-keperluan hidup istri-istri dan anak-anak mereka, adanya jaminan bahwa suami akan berlaku adil terhadap istri-istri dan anak-anak.

Memperkuat dan juga meneguhkan dalil-dalil Pemohon yang bersangkutan telah memberikan bukti-bukti surat mulai dari P.1 sampai dengan surat P.4, serta menghadirkan dua orang saksi. Paling penting adanya surat P.4 ini adalah bukti bahwa Termohon atau Istri Pemohon tidak keberatan untuk dimadu oleh Pemohon yang sebagaimana telah tercantum dalam Pasal 5 ayat (1) Undang-undang Nomor 1 Tahun 1974. Tindakan yang diperiksa dan dilakukan oleh hakim Pengadilan Agama Sidoarjo adalah mengabaikan UndangUndang Perkawinan No. 1 Tahun 1974 pada pasal 4 ayat (1) karena dirasa di dalam kitab suci Al-Quran itu tidak menjelaskan secara rinci alasan dalam berpoligami asalkan sang suami ini mampu berbuat adil dan itu tidak mengganggu hukum acara dan yang dicari adalah kebenaran formil yang ada didalam persidangan tersebut. namun dalam hal ini pula perlu menjadi satu sisi yang selalu diawasi, jika hanya bersedia adil dengan membuat pernyataan adil oleh sang suami, karena bisa saja orang ingin berpoligami ini hanya karena alasan nafsu belaka dan begitu mudahnya untuk menerima alasan tersebut. Ini juga sama saja pengadilan memberikan celah hukum bagi Pemohon lainnya untuk melakukan poligami. Padahal undangundang ini dibuat untuk diterapkan dan juga ditegakkan untuk meminimalisir orang-orang poligami dengan alasannya yang tidak dapat diterima oleh undang-undang yang bisa berakibat fatal terhadap keluarga-keluarganya nanti.

32 Tim Permata Press, Kompilasi Hukum Islam (KHI) Hukum Perkawinan, Kewarisan, dan Perwakafan, 18. 
Adapun pertimbangan hakim atas permohonan perkara izin poligami ini menggunakan ketentuan dalam Al-Quran surat AnNisa' ayat 3 tentang poligami yang diambil alih oleh hakim sebagai landasan hukum dan juga menjadi pertimbangan majelis hakim yaitu sebagai berikut:

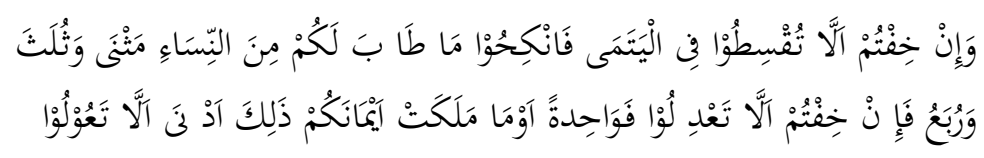

Artinya: Dan jika kamu takut tidak akan dapat berlaku adil terhadap (bak-bak) perempuan yang yatim (bilamana kamu mengawininya), maka kawiniah wanita-wanita (lain) yang kamu senangi; dua, tiga atau empat. Kemudian jika kamu takut tidak akan dapat berlaku adil, maka kawininilah seseorang saja, atau budak-budak yang kamu miliki. Yang demikian itu lebih dekat kepada tidak berbuat aniaya" (Q.S. An-Nisa: 3) 33

Terdapat ayat di atas dalam pandangan yaitu Wahbah Zuhaily yang telah disebutkan di dalam kitabnya yang bernama $A l-M u n i>r$, bahwa seorang suami diperbolehkan dan diperkenankan untuk melakukan pernikahan lebih dari seorang istri yang biasa disebut dengan berpoligami. Namun poligami di sini tentu mempunyai persyaratan yang lumayan cukup ketat untuk melakukannya, dan persyaratan tersebut tidak lain dan tidak bukan adalah seorang suami tersebut mampu untuk berlaku adil terhadap istri-istrinya baik dari segi materi dan non materii, baik adil dari segi lahir dan juga batin, dan juga menyangkut segala kebutuhan para istri-istrinya. Apabila ia mampu maka itu dibolehkan untuknya, namun apabila sebaliknya ia tidak mampu untuk berlaku adil maka Islam sendiri tidak memperbolehkannya untuk melakukan pernikahan lebih dari seorang atau biasa yang disebut dengan poligami.

Sayyid Qutub mengatakan bahwa poligami merupakan suatu Perbuatan Rukhsah. Karena merupakan Rukhsah., maka bisa dilakukan hanya dalam keadaan darurat, dan yang benar-benar mendesak. Kebolehan ini masih diisyaratkan berbuat adil terhadap

33 Departemen Agama Republik Indonesia, Al Quran Terjemah Indonesia, Jakarta: Departemen RI, 1988), 140. 
istri-istrinya. Keadilan yang dituntut disini dalam bidang nafkah, mu'amalah, pergaulan, serta pembagian malam. Sedangkan bagi calon suami yang tidak bisa berbuat adil, maka diharuskan cukup satu saja. Jika kita lihat dari segi pandangan kewanitaan akan jelas bahwa jalan yang di berikan Islam ini memperlihatkan betapa Islam sangat menghormati eksistensi wanita, memberikan hak-haknya, mengakui keinginan dan kebutuhannya untuk mendapatkan pasangan, memberikan tempat kepadanya di masyarakat.34

Bagi para penegak hukum yang telah ditentukan dan dibuatkan undang-undang perkawinan untuk beristri lebih dari seorang atau poligami untuk mematuhi syarat-syarat yang telah ada yakni adanya syarat alternatif dimana syarat itu haruslah memiliki salah satu dari alasan tersebut. Perlunya juga mendukung pemerintah utnuk menegakkan hukum yakni undang-undang yang telah diatur dan ditentukan untuk berpoligami adalah salah satu cara untuk menegakkan hukum yang telah ada, apabila terus berpijak pada sisi toleransi hukum hakim yang mengenyampingkan Peraturan Perundang-Undangan No. 1 Tahun 1974 Tentang Perkawinan dan juga yang telah terdapat dalam KHI (Kompilasi Hukum Islam) tersebut, maka pastinya perundang-undangan ini akan selalu dilanggar oleh pelaku poligami yang lainnya terutama seorang Pemohon/Suami.

Memutuskan perkara tersebut, hakim tetap berpijak pada Undang-undang No. 1 Tahun 1974 Tentang Perkawinan yang terdapat dalam pasal 5 ayat (1). Bahwa ketentuan pasal 5 ayat (1) tersebut diatas merupakan syarat kumulatif yang secara keseluruhan harus dipenuhi oleh Pemohon sebagai alasan mengajukan permohonan izin untuk menikah lagi. Akan tetapi dalam hal lain terutama dalam pasal sebelumnya yakni pasal 4 ayat (1) tidak ada satupun persyaratan yang memenuhi persyaratan alternatif tersebut. Pada Kompilasi Hukum Islam (KHI) Tentang Beristri lebih satu orang telah tercantum peraturan Pada Pasal 55 ayat (2) yang berbunyi "Syarat utama beristri lebih dari seorang, suami harus mampu berlaku adil terhadap istri-istri dan anak-anaknya".

34 Sayyid Qutub, Fi Dhilal Al-Qura'n, (Dar Al-Kutub Al-Ilmiyah, 1961), IV, 236. 
Muahammad Salim: Diterimanya Izin Poligami...

Hakim melakukan hal tersebut adalah sebagai salah satu bagaimana cara hakim untuk merealisasikan prinsip kemandirian dan juga kebebasan hakim yang sebagaimana telah ditentukan dalam kekuasaan kehakiman yang terdapat dalam Undang-undang No. 7 Tahun 1989 Jo. Undang-undang No. 3 Tahun 2006. Salah satu tanda dan juga syarat dalam kekokohan negara hukum adalah terdapat kekuatan yang kuat dalam kehakiman yang merdeka tanpa adanya intervensi dalam hal apapun dan dari siapapun.

Apabila tanpa adanya kekuasaan kehakiman maka hukumhukum yang ada di Indonesia ini akan mudah terpengaruh dan juga dapat disalahgunakan kebijakan hukum oleh kekuasaan pemerintah (eksekutif). Adapun dasar yang dijadikan hakim adanya indepedensi kekuasaan kehakiman ini telah tertuang dalam alinea pertama dalam lembaran Undang-undang No. 48 Tahun 2009 tentang kekuasaan kehakiman, terdapat dalam penjelasan pada Pasal 24 ayat (1) UUD 1945 dengan tegasnya telah menyatakan bahwa:

Pasal 24 ayat (1) :

"kekuasaan kehakiman adalah kekuasaan yang merdeka, artinya terlepas dari pengarub kekuasaan pemerintah. Berbubung dengan itu, harus diadakan jaminan dalam undang-undang tentang kedudukan para bakim".

\section{Penutup}

Dasar pertimbangan hakim Pengadilan Agama Sidoarjo adalah pertama, Melihat Kondisi Mental Calon Istri Kedua Pemohon yang Trauma Akibat Kekerasan dalam Rumah Tangga, Hakim menilai resiko yang akan dihadapi oleh Pemohon dan Termohon lebih besar jika tidak diizinkannya melakukan Poligami. Kedua, Berlandaskan AlQuran yang Memberikan Persyaratan Adil Semata. Ketiga, Sudah Adanya Persetujuan dari Istri Pertama dan Juga Terpenuhi Secara Materi Maupun Non Materi oleh Pemohon dan Sanggup Adil dengan Membuat Surat Pernyataan, dan Hakim Apabila Keduanya Ini Sudah Terpenuhi Maka Diperbolehkannya untuk Diberikan Izin Poligami.

Adapun analisis dalam perkara ini adalah bahwa alasan poligami oleh Pemohon ini adalah karena ingin mendidik dan menolong calon istri sesuai dengan sunnah Nabi Muhammad Saw yang berbeda dari peraturan undang-undang yang berlaku. hakim 
mengabulkan permohonan pemohon dalam hal poligami. Hakim boleh saja memberikan putusan yang berbeda dari undang-undang, akan tetapi jika itu terus dilakukan maka pembatasan dalam peraturan poligami secara ketat yang telah dibuat oleh pemerintah yang tertulis di undang-undang akan lemah kekuatan hukumnya. Dan Penulis setuju apa yang telah dilakukan oleh hakim dikarenakan hakim dinilai telah tepat dan telah sesuai dengan Pasal 4 ayat 2 Undang-undang No.1 Tahun 1974 dan Undang-undang No. 48 tahun 2009 tentang kekuasaan kehakiman pada pasal 1 ayat 1.

\section{Daftar Pustaka}

Abd. Rahman Ghazaly. Fiqh Munakahat, Bogor: Kencana, 2003.

Abdul Manan. Aneka Masalah Hukum Perdata Islam di Indonesia. Jakarta: Kencana, 2006

Agus Mustofa. Poligami Yunk!! Surabaya: Padra Press, 2010.

Amiur Nuruddin, Azhari Akmal Tarigan, Hukum Perdata Islam di Indonesia, Jakarta: Kencana, 2004.

Chuzaimah T. Yanggo dan Hafiz Anshory AZ, Problematika Hukum Islam dan Kontemporer, Jakarta: Pustaka Firdaus, 1996.

Ibnu Mustafa, Perkawinan Mut'ab dalam Perspektif Hadist dan Tinjauan Masakini, Jakarta: Lentera, 1999.

Idris Ramulyo, Hukum Perkawinan Islam, Jakarta: Bumi Aksara, 1999. Sayyid Qutub, Fi Dhilal Al-Qura'n, Dar Al-Kutub Al-Ilmiyah, 1961. Slamet Abidin dan Aminuddin, Fiqih Munakahat 1 Untuk. Fakultas Syariah Komponen MKDK (Bandung: Pustaka Setia, 1999) 132. Yusuf Qaradhawi, Hal wal Haram fil Islam, yang diterjemahkan oleh Tim Kuadran dengan judul Halal dan Haram, Bandung: Penerbit Jabal, 2007.

Departemen Agama Republik Indonesia, Al Quran Terjemah Indonesia, Jakarta: Departemen RI, 1988.

Team Prospect, Kumpulan Kitab Undang-Undang Hukum KUH Perdata KUHP KUHAP, Jakarta: Wipress, 2008.

Tim Permata Press, Kompilasi Hukum Islam (KHI) Hukum Perkawinan, Kewarisan, dan Perwakafan, 17.

Hj. Siti Aisyah, S.Ag, M.HP, Hakim Pengadilan Agama Sidoarjo, Wawancara, Sidoarjo, 09 April 2017. 